\title{
Prognostic value of histopathology and trends in cervical cancer: a SEER population study
}

\author{
Vincent Vinh-Hung*1,2, Claire Bourgain ${ }^{1}$, Georges Vlastos ${ }^{3}$, Gábor Cserni ${ }^{4}$, \\ Mark De Ridder ${ }^{1}$, Guy Storme ${ }^{1}$ and Anne-Thérèse Vlastos ${ }^{3}$
}

\begin{abstract}
Address: ${ }^{1}$ Oncologisch Centrum, Universitair Ziekenhuis Brussel, 101 Laarbeeklaan, 1090 Jette, Brussels, Belgium, ${ }^{2}$ Geneva Cancer Registry, Institute for Social and Preventive Medicine, University of Geneva, Geneva, Switzerland, ${ }^{3}$ Hôpitaux Universitaires de Genève, Geneva, Switzerland and ${ }^{4}$ Cserni BT and Bács-Kiskun County Teaching Hospital, Kecskemét, Hungary

Email: Vincent Vinh-Hung* - conrvhgv@uzbrussel.be; Claire Bourgain - Claire.Bourgain@uzbrussel.be; Georges Vlastos - georges.vlastos@hcuge.ch; Gábor Cserni - cserni@freemail.hu; Mark De Ridder - Mark.DeRidder@uzbrussel.be; Guy Storme - Guy.Storme@uzbrussel.be; Anne-Thérèse Vlastos - Anne-Therese.Vlastos@hcuge.ch

* Corresponding author
\end{abstract}

Published: 23 August 2007

BMC Cancer 2007, 7:164 doi:10.1 186/147|-2407-7-164
Received: 17 April 2007

Accepted: 23 August 2007

This article is available from: http://www.biomedcentral.com/I47/-2407/7//64

(c) 2007 Vinh-Hung et al; licensee BioMed Central Ltd.

This is an Open Access article distributed under the terms of the Creative Commons Attribution License (http://creativecommons.org/licenses/by/2.0), which permits unrestricted use, distribution, and reproduction in any medium, provided the original work is properly cited.

\begin{abstract}
Background: Histopathology is a cornerstone in the diagnosis of cervical cancer but the prognostic value is controversial.

Methods: Women under active follow-up for histologically confirmed primary invasive cervical cancer were selected from the United States Surveillance, Epidemiology, and End Results (SEER) 9registries public use data 1973-2002. Only histologies with at least 100 cases were retained. Registry area, age, marital status, race, year of diagnosis, tumor histology, grade, stage, tumor size, number of positive nodes, number of examined nodes, odds of nodal involvement, extent of surgery, and radiotherapy were evaluated in Cox models by stepwise selection using the Akaike Information Criteria.
\end{abstract}

Results: There were 30,989 records evaluable. From 1973 to 2002, number of cases dropped from I, 100 new cases/year to 900/year, but adenocarcinomas and adenosquamous carcinoma increased from 100/year to 235/year. Median age was 48 years. Statistically significant variables for both overall and cause-specific mortality were: age, year of diagnosis, race, stage, histology, grade, hysterectomy, radiotherapy, tumor size and nodal ratio. The histological types were jointly significant, $P<0.001$. Cause-specific mortality hazard ratios by histological type relatively to nonmicroinvasive squamous cell carcinoma were: microinvasive squamous cell carcinoma 0.28 (95\% confidence interval: $0.20-0.39)$, carcinoma not otherwise specified 0.91 (0.79-I.04), non-mucinous adenocarcinoma $\mathrm{I} .06$ (0.98-I.I5), adenosquamous carcinoma $\mathrm{I} .35$ (I.20-I.5I), mucinous adenocarcinoma I.52 (I.23-I.88), small cell carcinoma I.94 (I.58-2.39).

Conclusion: Small cell carcinoma and adenocarcinomas were associated with poorer survival. The incidental observation of increasing numbers of adenocarcinomas despite a general decline suggests the inefficiency of conventional screening for these tumors. Increased incidence of adenocarcinomas, their adverse prognosis, and the young age at diagnosis indicate the need to identify women who are at risk. 


\section{Background}

Cancer of the cervix uteri is the second most common cancer (after breast cancer) and the third leading cancer mortality (after lung and breast cancer) among women worldwide [1]. Squamous cell carcinoma (SCC) is the predominant histological type accounting for three-fourths of all cervical cancers. Adenocarcinoma and adenosquamous cell carcinoma represent $10-15 \%$, and other or unspecified histology represent the remaining 10-15\% $[2,3]$. There is controversy regarding whether or not these different histological types have any bearing on prognosis [4-7]. Some authors found that adenocarcinoma had a poor prognosis $[8,9]$, others found no evidence of pathological type as a risk factor $[6,10]$. Since histopathology is a cornerstone in the detection and the diagnosis of cervical cancer, we believe that clarifying the prognostic value of pathological type is an important issue that might influence the management, treatment and surveillance planning of newly diagnosed cervical cancer. The present study uses the United States Surveillance, Epidemiology, and End Results (SEER) population data in order to evaluate the prognostic role of histopathological type in invasive carcinoma of the cervix.

\section{Methods}

Records of patients under active follow-up were abstracted from the 9-registries of the SEER [11]. Selected patients were women with histologically confirmed primary invasive cervical cancer diagnosed between 1973 and 2002. Tumor histopathologies were classified according to the SEER's implementation of the International Classification of Diseases for Oncology (ICDO), Second Edition [11]. Only histopathological types with at least 100 cases were retained.

Univariate analyses of overall survival (event = death from any cause) and cause-specific survival (event = death from cervical cancer) used the Kaplan-Meier method [12].

Multivariate analyses used the proportional hazards models. The selection of variables combined backward and forward stepwise selection by minimizing the Akaike Information Criteria (AIC) [13]. The AIC is computed as minus twice the log likelihood plus twice the number of parameters of the model. The AIC penalizes over-parameterization, variables are retained only when the model improves enough to balance the number of parameters. The variables evaluated were: SEER registry area, age, marital status, race, tumor histopathology, grade, historical stage (localized versus regional, metastatic, or unknown), extent of surgery (hysterectomy versus else), radiotherapy (prescribed versus none or unknown). Up to four levels of interactions were considered in the stepwise selection. More detailed pathological data and AJCC (American Joint Committee on Cancer) stage was available in a sub- set of patients. A second analysis was done on that subset with the detailed variables: AJCC stage, tumor size, number of removed nodes, number of positive nodes, and log odds of nodal involvement computed as Log ((number of positive nodes +0.5$) /$ (number of negative nodes +0.5$))[14]$. The log odds was used to generalize the lymph node ratio to node-negative cases. The assumption of proportional hazards were checked using the Schoenfeld residuals method [15] [see Additional File 1]. The linearity of the functional forms of continuous variables were verified using the martingale residuals [15] [see Additional File 2].

For purpose of condensing the report, histopathological types were grouped as: carcinoma not otherwise specified (ICDO 8010), squamous cell carcinoma microinvasive (8076), non-microinvasive squamous cell carcinoma $(8070,8071,8072)$, adenosquamous carcinoma (8560), adenocarcinoma excluding mucinous $(8140,8260,8310$, 8380), mucinous adenocarcinoma (8480, 8481), and small cell carcinoma (8041).

\section{Results}

\section{Trends and characteristics}

There were 32,040 cases of histologically confirmed primary invasive cancer of the cervix and 81 histological types. Among these, 30,989 records matched the selection criteria, representing the study population, with 13 histological types. The median follow-up was 10.5 years. The predominant histopathological types were invasive squamous cell carcinomas (SCC) accounting for two thirds of the incidence $(n=20,755)$. There were notable changes in the counts of recorded cases over the last three decades. The overall number of cases diagnosed each year declined from an average of 1,100 cases per year (peak 1,1091,215 per year in 1975-1976) to an average of 900 cases per year (893-871 in 2000-2002) (Figure 1). In terms of crude incidence rates, these correspond to a decline from 11.1 to 6.6 cases per 100,000 women per year. Most of the decline could be attributed to the decline in the incidence of SCC (Figure 1). The yearly count of carcinoma not otherwise specified (NOS) also declined from an average of 95 per year in 1975 to an average of 30 per year in 2000. However, the yearly count of adenocarcinomas increased: non-mucinous from an average of 80 per year (73-89 in $1973-1975)$ to 175 per year (166-179 in 2000-2002), adenosquamous from an average of 20 per year (13-29 in 1973-1975) to 45 per year (46-41 in 2000-2002), mucinous from almost none (1-3 cases per year in 1973$1975)$ to 15 per year (11-17 in 2000-2002) (Figure 1).

Table 1 shows the distribution of patients and tumor characteristics according to the histopathology group. Women were young in all histological groups. The lowest median age was 38 years in microinvasive SCC, the highest 

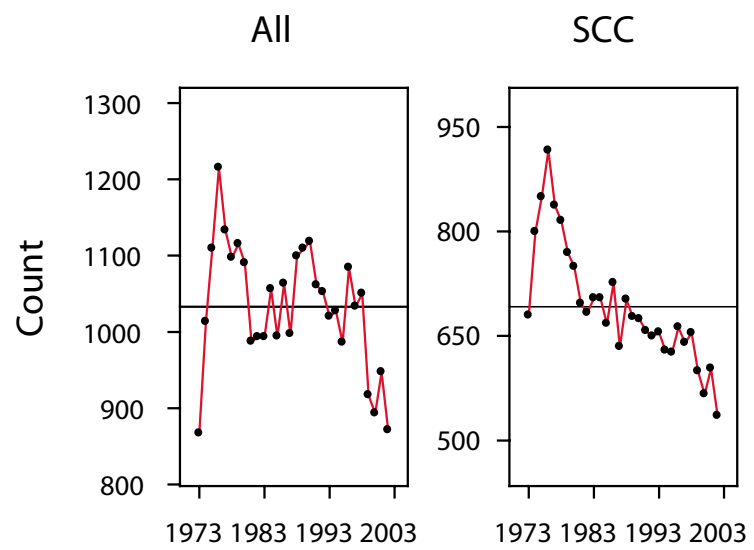

Carc. NOS

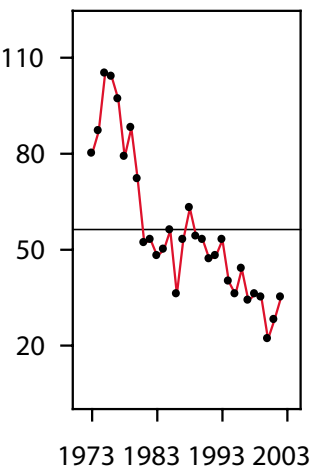

Adeno. excl. muc.

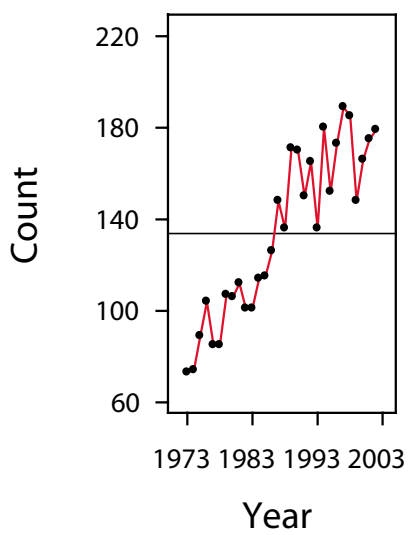

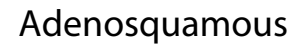

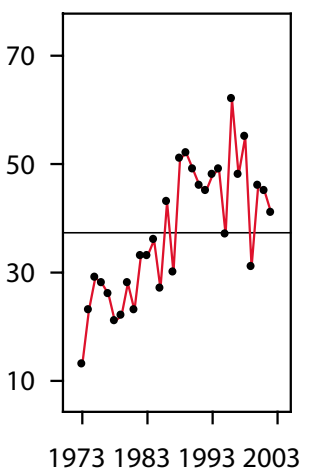

Year

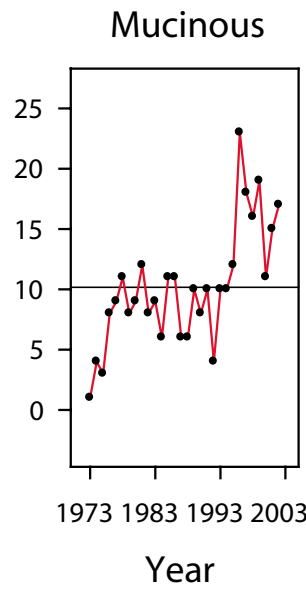

Microinvasive

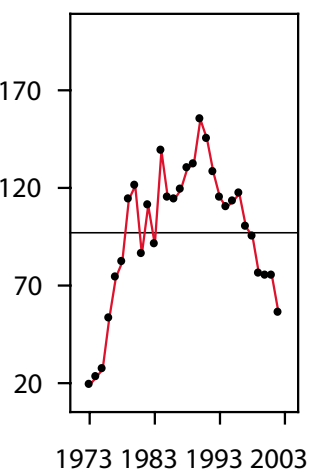

Small Cell

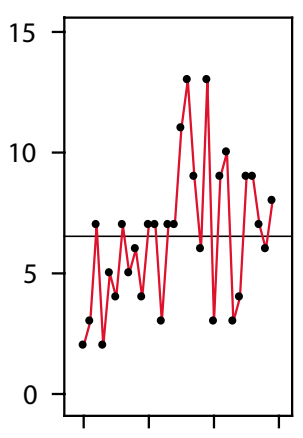

1973198319932003

Year

\section{Figure I}

Numbers of new cervical cancers, by histopathological type. All graphs are centered around the mean number of cases per year (horizontal line). The vertical axes are scaled to highlight the trend within each histopathological type.

median age was 50 years in SCC and in mucinous adenocarcinoma, the overall median age was 48 years. By race, the distribution of histological types were comparable between White Non-Hispanic and White Hispanic women. The distribution differed in African-American women in whom squamous cell types were relatively more frequent than adenocarcinomas. By tumor characteristics, non-mucinous adenocarcinomas were associated with smaller tumor size (median $25 \mathrm{~mm}$ ), less nodal involvement (log odds -3.6), less advanced stage $(71 \%$ stage I, $10 \%$ stage II) as compared with SCC (median tumor size $40 \mathrm{~mm}$, log odds nodal involvement -3.4, 51\% stage I, 19\% stage II). Small cell carcinoma was associated with the most advanced tumor involvement (median tumor size $45 \mathrm{~mm}$, log odds nodal involvement -2.7,32\% stage I, $14 \%$ stage II). Adenosquamous and mucinous carcinomas were associated with intermediary characteristics. Information on surgery was available in 17,994 records. Hysterectomy was generally performed in more than half of the cases. Information on whether or not radiotherapy had been prescribed was available in 30,747 records. Radiotherapy was performed in about $60 \%$ of these cases, except microinvasive SCC and unspecified carcinoma for which respectively only $4 \%$ and $26 \%$ received some form of radiotherapy.

\section{Unadjusted survival analyses}

The 10-year overall survival was $57.8 \%$ (95\% confidence interval $57.2 \%-58.4 \%$ ) and the 10 -year cause-specific survival was $74.2 \%(73.7 \%-74.8 \%)$. There were large statistically significant differences of overall survival between the histological groups $(\mathrm{P}<0.0001)$ (Figure $2-\mathrm{a})$. The longest overall survival was observed with microinvasive SCC $(90.6 \%$ at 10 -year) and the poorest survival was observed with small cell carcinoma (31.6\% at 10 -year) (Table 2 and Figure 2-a). Between these two groups, the 
Table I: Invasive tumors: patient and tumor characteristics by histological type

\begin{tabular}{|c|c|c|c|c|c|c|c|c|}
\hline $\begin{array}{l}\text { Characteris } \\
\text { tic }\end{array}$ & $\begin{array}{c}\text { Non- } \\
\text { missi } \\
\text { ng } \\
\text { data }\end{array}$ & $\begin{array}{l}\text { Microinvasiv } \\
\text { e SCC }\end{array}$ & $\begin{array}{c}\text { Carcinoma } \\
\text { not } \\
\text { otherwise } \\
\text { specified } \\
n=1688\end{array}$ & $\begin{array}{l}\text { Squamous } \\
\text { Cell (SCC) }\end{array}$ & $\begin{array}{l}\begin{array}{c}\text { Adenoca. } \\
\text { excl. } \\
\text { mucinous }\end{array} \\
\mathrm{n}=4015\end{array}$ & $\begin{array}{l}\text { Adeno- } \\
\text { squamous }\end{array}$ & $\begin{array}{c}\begin{array}{c}\text { Mucinous } \\
\text { adeno- } \\
\text { carcinoma }\end{array} \\
\mathrm{n}=305\end{array}$ & $\begin{array}{l}\text { Small cell } \\
\text { carcinoma }\end{array}$ \\
\hline Age (I) & 30989 & $38(3 \mid \sim 48)$ & $42(32 \sim 58)$ & $50(39 \sim 64)$ & 47 (37 62) & $44(36 \sim 57)$ & $50(4 \mid \sim 66)$ & $48(35 \sim 63)$ \\
\hline $\begin{array}{l}\text { Marital status } \\
\text { (married) }^{(2)}\end{array}$ & 27999 & $|45|$ (55\%) & 736 (52\%) & 9193 (49\%) & $2102(58 \%)$ & 548 (53\%) & $160(57 \%)$ & $95(51 \%)$ \\
\hline Race & 30764 & & & & & & & \\
\hline $\begin{array}{l}\text { White } \\
\text { non-hisp (2) }\end{array}$ & & $204 \mid$ (7I\%) & 1191 (72\%) & I 3797 (67\%) & 3066 (77\%) & 785 (70\%) & $229(75 \%)$ & $127(65 \%)$ \\
\hline $\begin{array}{l}\text { White } \\
\text { hispanic (2) }\end{array}$ & & $199(7 \%)$ & $96(6 \%)$ & $167 \mid(8 \%)$ & $236(6 \%)$ & 75 (7\%) & $19(6 \%)$ & $14(7 \%)$ \\
\hline Black (2) & & $362(13 \%)$ & $278(17 \%)$ & $3430(17 \%)$ & $318(8 \%)$ & 157 (I4\%) & $23(8 \%)$ & 21 (II\%) \\
\hline Other (2) & & 279 (10\%) & $95(6 \%)$ & $1735(8 \%)$ & 357 (9\%) & 97 (9\%) & 34 (II\%) & 32 (16\%) \\
\hline $\begin{array}{l}\text { Tumor size } \\
(\mathrm{mm})^{(\mathrm{I})(3)}\end{array}$ & 6352 & $\mathrm{I}(\mathrm{I} \sim 2)$ & $2(I \sim 53)$ & $40(17 \sim 60)$ & $25(10 \sim 45)$ & $30(20 \sim 50)$ & $29(20 \sim 47)$ & 45 (29 69) \\
\hline $\begin{array}{l}\text { High } \\
\text { histological } \\
\text { grade (2) }\end{array}$ & 16378 & $95(28 \%)$ & 248 (86\%) & $5722(49 \%)$ & 821 (28\%) & 485 (70\%) & $61(26 \%)$ & 142 (100\%) \\
\hline $\begin{array}{l}\text { Number of } \\
\text { nodes } \\
\text { removed (I)(4) }\end{array}$ & 14178 & $0(0-0)$ & $0(0-0)$ & $0(0-9)$ & $0(0-17)$ & I (0-I8) & $5(0-2 I)$ & $0(0-11)$ \\
\hline $\begin{array}{l}\text { Node- } \\
\text { positive status } \\
\text { (2) }\end{array}$ & 5243 & I (0\%) & $9(18 \%)$ & 679 (21\%) & 143 (I2\%) & 92 (24\%) & $33(29 \%)$ & 21 (48\%) \\
\hline $\begin{array}{l}\text { Log odds } \\
\text { nodal } \\
\text { involvement } \\
\text { (I)(5) }\end{array}$ & 4497 & $-3.4(-3.9 \sim-2.9)$ & $-3.1(-3.7 \sim-1.9)$ & $-3.4(-3.9 \sim-2.5)$ & $-3.6(-3.9 \sim-2.9)$ & $-3.3(-3.8 \sim-2.3)$ & $-3.4(-3.9 \sim-1.9)$ & $-2.7(-3.7 \sim-1.2)$ \\
\hline \multicolumn{9}{|l|}{$\begin{array}{l}\text { AJCC Stage } \\
(6)\end{array}$} \\
\hline I (2) & 8831 & I 583 (99\%) & $373(70 \%)$ & 4674 (51\%) & 1657 (7I\%) & 407 (60\%) & $100(54 \%)$ & 37 (32\%) \\
\hline II (2) & 2104 & II (I\%) & $51(10 \%)$ & 1708 (19\%) & $226(10 \%)$ & 74 (II\%) & $18(10 \%)$ & $16(14 \%)$ \\
\hline III (2) & 2223 & $7(0 \%)$ & $50(9 \%)$ & $177 \mid(20 \%)$ & $216(9 \%)$ & $115(17 \%)$ & 35 (19\%) & 29 (25\%) \\
\hline IV (2) & 1358 & $4(0 \%)$ & 61 (11\%) & 925 (10\%) & $226(10 \%)$ & 77 (II\%) & $31(17 \%)$ & 34 (29\%) \\
\hline $\begin{array}{l}\text { Hysterectom } \\
y^{(2)}\end{array}$ & 17994 & I553 (72\%) & 364 (46\%) & $5302(48 \%)$ & $1966(68 \%)$ & $540(67 \%)$ & 146 (69\%) & 63 (47\%) \\
\hline $\begin{array}{l}\text { Radiotherapy } \\
\text { (2) }\end{array}$ & 30747 & $128(4 \%)$ & 435 (26\%) & I 3084 (64\%) & 1819 (46\%) & $643(58 \%)$ & $183(60 \%)$ & 120 (62\%) \\
\hline
\end{tabular}

(I) Values are: median (lower upper quartiles).

(2) Values are: number of patients (\%). Rounded percentages are computed excluding cases with missing data.

(3) Tumor size: I = microscopic focus or foci; $2=$ non-microscopic but $<=2 \mathrm{~mm}$.

(4) 9678 cases 0 node examined, 4500 cases with $>=$ I node examined.

(5) Log ((number of positive nodes +0.5$) /($ number of negative nodes +0.5$)$ ). More negative values indicate lower risk of nodal involvement [14].

(6) SEER modified stage grouping: Nx cases (unknown nodal status) are grouped according to the T-stage.

ranking from longer to shorter survival was: carcinoma NOS, non-mucinous adenocarcinoma, invasive SCC, adenosquamous carcinoma, and mucinous adenocarcinoma. The ranking of the histopathological groups by cause-specific survival was comparable, from the best cause-specific survival observed with microinvasive SCC (98.7\% at 10year), to the poorest survival observed with small cell carcinoma (44.5\%) (Table 2 ).

\section{Multivariate analysis}

In a multivariate analysis for overall mortality, the variables retained by the stepwise selection were: SEER registry area, age at diagnosis, year of diagnosis, race, marital sta- tus, histological type, histological grade, stage, type of surgery, radiotherapy, and interactions between stage, surgery, and radiotherapy [see Additional File 3]. Figure 2b shows the survival according to the histopathological group that would have been expected after adjustment by that stepwise selection. For cause-specific mortality, the SEER registry area and marital status were not significant while all other variables were significant (Table 3). Histology was among the most significant factors, regardless of whether the analysis was done using grouped histologies or whether the analysis was done using the distinct histological subtypes. 
Table 2: Kaplan-Meier estimates of overall survival and cause-specific survival by histopathology

\begin{tabular}{|c|c|c|c|c|}
\hline Histology & $\begin{array}{l}\text { ICDO 4- } \\
\text { digits }\end{array}$ & $\mathbf{n}$ & $\begin{array}{l}10 \text { year overall survival ( } 95 \% \\
\text { confidence interval) }\end{array}$ & $\begin{array}{l}10 \text { year cause-specific survival } \\
\text { (95\% confidence interval) }\end{array}$ \\
\hline All & & 30989 & $57.8(57.2-58.4)$ & $74.2(73.7-74.8)$ \\
\hline $\begin{array}{l}\text { Carcinoma not otherwise } \\
\text { specified (NOS) }\end{array}$ & 8010 & 1688 & 71.1 (68.9-73.4) & $84.9(83.1-86.7)$ \\
\hline $\begin{array}{l}\text { Squamous cell carcinoma } \\
\text { microinvasive }\end{array}$ & 8076 & 2910 & $90.6(89.4-91.8)$ & 98.7 (98.2-99.1) \\
\hline $\begin{array}{l}\text { Squamous cell carcinoma } \\
\text { (SCC) }\end{array}$ & & 20755 & $52.3(51.5-53.0)$ & $69.7(69.1-70.4)$ \\
\hline $\begin{array}{l}\text { SCC nonkeratinizing, } \\
\text { NOS }\end{array}$ & 8072 & 2692 & $54.9(52.9-57.0)$ & $69.1(67.1-71.0)$ \\
\hline $\begin{array}{l}\text { SCC large cell, } \\
\text { keratinizing }\end{array}$ & 8071 & 2373 & $54.4(52.2-56.6)$ & $69.0(66.9-71.1)$ \\
\hline SCCNOS & 8070 & 15690 & $51.6(50.7-52.4)$ & $70.0(69.2-70.8)$ \\
\hline $\begin{array}{l}\text { Adenosquamous } \\
\text { carcinoma }\end{array}$ & 8560 & 1120 & $50.7(47.5-53.9)$ & $66.6(63.5-69.7)$ \\
\hline $\begin{array}{l}\text { Adenocarcinoma } \\
\text { excluding mucinous }\end{array}$ & & 4015 & $60.9(59.2-62.6)$ & $77.9(76.4-79.3)$ \\
\hline $\begin{array}{l}\text { Endometrioid } \\
\text { carcinoma }\end{array}$ & 8380 & 198 & $68.9(59.9-78.0)$ & $87.9(80.7-95.1)$ \\
\hline Adenocarcinoma NOS & 8140 & 3302 & $61.5(59.7-63.4)$ & $77.3(75.7-79.0)$ \\
\hline $\begin{array}{l}\text { Papillary } \\
\text { adenocarcinoma, NOS }\end{array}$ & 8260 & 348 & $58.9(53.4-64.4)$ & $81.9(77.3-86.4)$ \\
\hline $\begin{array}{l}\text { Clear cell } \\
\text { adenocarcinoma, NOS }\end{array}$ & 8310 & 167 & $47.1(38.6-55.5)$ & $68.2(59.9-76.4)$ \\
\hline $\begin{array}{l}\text { Mucinous } \\
\text { adenocarcinoma }\end{array}$ & & 305 & $43.0(36.5-49.5)$ & $62.1(55.4-68.8)$ \\
\hline $\begin{array}{l}\text { Mucous } \\
\text { adenocarcinoma }\end{array}$ & 8480 & 181 & $43.6(34.2-53.1)$ & $64.1(54.7-73.6)$ \\
\hline $\begin{array}{l}\text { Mucin-secreting } \\
\text { adenocarcinoma }\end{array}$ & 8481 & 124 & $41.3(32.1-50.5)$ & $59.1(49.2-68.9)$ \\
\hline $\begin{array}{l}\text { Small cell carcinoma } \\
\text { NOS }\end{array}$ & 8041 & 196 & $31.6(24.5-38.8)$ & $44.5(36.7-52.4)$ \\
\hline
\end{tabular}

The ranking of the histological groups from best to poorest overall survival were: SCC microinvasive (hazard ratio $\mathrm{HR}=0.28)$, carcinoma NOS $(\mathrm{HR}=0.91)$, SCC non-microinvasive (reference, $\mathrm{HR}=1$ ), non-mucinous adenocarcinoma $(\mathrm{HR}=1.06)$, adenosquamous $(\mathrm{HR}=1.35)$, mucinous $(\mathrm{HR}=1.52)$, and small cell carcinoma $(\mathrm{HR}=$ 1.94). The results of the same analysis but using the distinct histological types instead of groups are shown graphically in Figure 3. The hazard ratios ranged from the lowest risk histological types (SCC microinvasive, endometrioid, and papillary adenocarcinoma), through the intermediary risk types (the three SCC's and the adenocarcinoma NOS), to the highest risk types (clear cell adenocarcinoma, adenosquamous, mucin-secreting, mucous adenocarcinoma, and small cell carcinoma) (Figure 3).

\section{Analyses on reduced subsets}

There were 2,458 cases with information on tumor size, nodal involvement, and with non-missing AJCC staging. Table 4-A shows the results of the cause-specific analysis by stepwise selection applied to this subset of patients with more complete pathological data. The three variables of tumor size (log transformed to adjust for non-linearity), log odds of nodal involvement, and stage were retained, but not the number of positive nodes and the number of nodes removed. The SEER area, marital status, and radiotherapy were not significant. The histological groups were jointly significant $(\mathrm{P}<0.0001)$. Their ranking was comparable to Table 3 aside the non-significant SCC microinvasive and carcinoma NOS. We noted that the very large hazard ratio of small cell carcinoma might have inflated the joint significance of histology, hence the model was recomputed excluding it. The histological groups remained jointly significant $(P=0.02)$.

The analysis was repeated on the same subset in a model that deliberately ignored tumor size and nodal involvement, and used historical stage instead of AJCC stage (Table 4-B). SCC microinvasive and carcinoma NOS remained non significant and the hazard ratios of the other histological types were almost unchanged. Table 4B suggests that historical stage could be an acceptable sur- 
(a) Observed OS

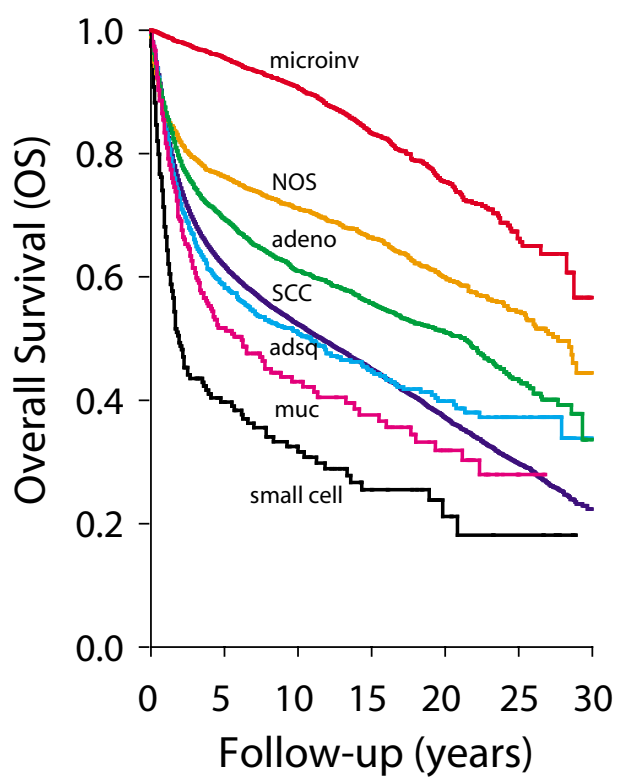

(b) Adjusted OS

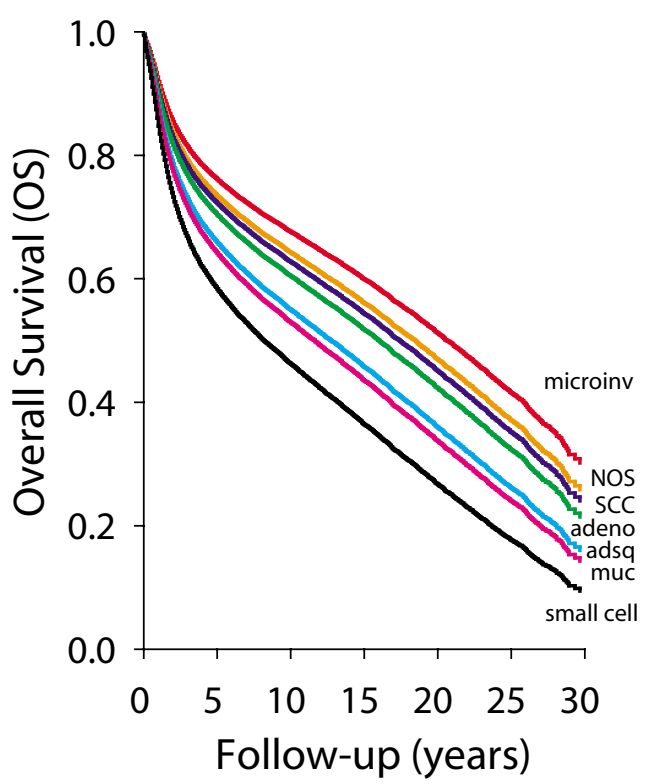

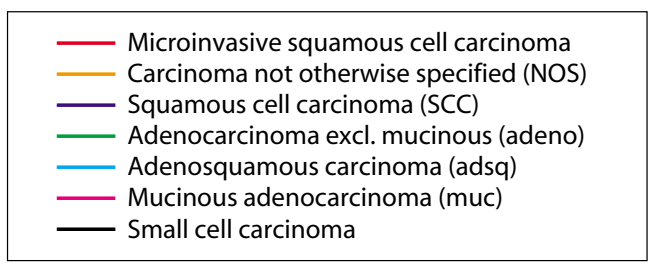

Figure 2

Overall survival by histopathology group. (a) Unadjusted Kaplan-Meier survival estimates. (b) Expected survival after adjustment taking into account registry area, age, year of diagnosis, race, marital status, grade, stage, surgery and radiotherapy, for a theoretical patient presenting with average characteristics of the population.

rogate to AJCC staging, but with a drawback: non-mucinous adenocarcinoma was non-significant in the incomplete model $(\mathrm{P}=0.078$, Table $4-\mathrm{B})$, whereas it was significant in the complete model $(\mathrm{P}=0.016$, Table $4-\mathrm{A})$.

\section{Discussion}

The incidence and mortality rates vary between countries with the highest rates observed in Latin America, South East Asia and Africa. The rates have declined in the last 40 years in industrialized countries, which reflect the success of screening [16-19]. Despite this success, the risks might remain high in the first generation of migrant populations [20-22]. In the United States, the age-standardized incidence and death rates are higher among African-American (11.1 new cases and 5.3 deaths per 100,000) and His-
panic-Latino (15.8 new cases and 3.5 deaths per 100,000) than among White women (8.7 new cases and 2.5 per $100,000)$ [23]. The incidence of cervical cancer begins to rise at age 20-29 years and increases rapidly to reach a peak usually around age 45-49 years in European populations [1]. The risk of developing an invasive cancer of the cervix is also higher in the age group 40 to 59 years in the US population [23]. The proportion of advanced stage in new invasive cervical cancer was 30\% among women aged $<50$ years and 52\% among women aged $>=50$ years [24]. For these reasons (worldwide population mobility, risk persistence in migrant populations, higher risk in minorities, early age occurrence, high proportion of advanced stages in newly diagnosed cases), cancer of the 
Table 3: Multivariate analysis of cause-specific mortality based on 30,989 cases of invasive cancer of the cervix

\begin{tabular}{|c|c|c|}
\hline Variable & $\begin{array}{c}\text { Hazard ratio( }(3)(95 \% \text { confi- } \\
\text { dence interval) }\end{array}$ & $\mathbf{P}$ \\
\hline \multicolumn{3}{|l|}{ Demographic characteristics } \\
\hline \multicolumn{3}{|l|}{ SEER area } \\
\hline Central registries & $0.95(0.89-1.01)$ & 0.099 \\
\hline Western registries & $0.97(0.91-1.03)$ & 0.308 \\
\hline Age at diagnosis & $1.01(1.00-1.01)$ & $<0.001$ \\
\hline Year of diagnosis & $1.00(1.00-1.01)$ & 0.013 \\
\hline African-American ethnicity (I) & $1.14(1.07-1.22)$ & $<0.001$ \\
\hline Marital status (married) (l) & $0.99(0.94-1.04)$ & 0.638 \\
\hline \multicolumn{3}{|l|}{ Pathology } \\
\hline Histological type (2) & & $<0.001$ \\
\hline SCC microinvasive & $0.28(0.20-0.39)$ & $<0.001$ \\
\hline Carcinoma not otherwise specified & $0.91(0.79-1.04)$ & 0.168 \\
\hline Adenocarcinoma excl. mucinous & $1.06(0.98-1.15)$ & 0.126 \\
\hline Adenosquamous carcinoma & $1.35(1.20-1.5 \mathrm{I})$ & $<0.001$ \\
\hline Mucinous & $1.52(1.23-1.88)$ & $<0.001$ \\
\hline Small cell & $1.94(1.58-2.39)$ & $<0.001$ \\
\hline Histological High grade (I) & $2.17(1.93-2.44)$ & $<0.001$ \\
\hline Localized stage $(1)$ & $0.07(0.05-0.08)$ & $<0.001$ \\
\hline \multicolumn{3}{|l|}{ Treatments and interactions } \\
\hline Hysterectomy (I) & $0.26(0.2|-0.3|)$ & $<0.001$ \\
\hline Radiotherapy (I) & $1.01(0.92-1.11)$ & 0.810 \\
\hline Hysterectomy * Radiotherapy & $2.05(1.67-2.52)$ & $<0.001$ \\
\hline High grade * Radiotherapy & $0.60(0.53-0.69)$ & $<0.001$ \\
\hline Localized stage * Hysterectomy & $2.87(2.17-3.78)$ & $<0.001$ \\
\hline Localized stage $*$ Radiotherapy & $5.24(4.36-6.29)$ & $<0.001$ \\
\hline Localized stage $*$ Hysterectomy $*$ Radiotherapy & $0.40(0.28-0.56)$ & $<0.001$ \\
\hline
\end{tabular}

(I) Binarized variable, coded I, versus all other levels of the variable including missing.

(2) Reference level = non-microinvasive squamous cell carcinoma (SCC), all types.

(3) Hazard ratio $>$ I indicates increased risk of dying from cervical cancer.

cervix is a major healthcare issue even in countries where the incidence has declined.

The present data confirms the overall declining incidence of cervical cancer, but contrasting with an increasing number of adenocarcinomas and adenosquamous carcinomas (Figure 1). Improved classification might have contributed to an apparent increase of adenocarcinomas. Carcinomas that were previously unspecified might have been better characterized in the more recent years, and therefore the increase of adenocarcinomas would reflect only a change in the classifications of the pathological diagnoses. However, the average drop of unspecified carcinomas over three decades was 65/year $(=95-30)$, whereas the average increase of adenocarcimas was 135/ year (non-mucinous 175-80 $=95 /$ year, adenosquamous $45-20=25 /$ year, mucinous $15-0=15 /$ year $)$, that is, the increase of adenocarcinomas was twice the decline of unspecified carcinomas. Hence a change of classification is insufficient to explain the increase [25]. Many authors have also reported an increasing incidence of adenocarcinomas particularly in younger women $[1,2,25-31]$.

In order to gain an understanding of these trends, we need to consider the current knowledge about the cause(s) of cervical cancer. There is ample experimental and epidemiological evidence that human papillomavirus (HPV) have a key role in cervical carcinogenesis [32-38]. The association of HPV with adenocarcinomas is similar to that with squamous cell carcinomas [39-46], though differing by the role of cofactors, such as tobacco smoking and parity associated with squamous cell carcinomas but not with adenocarcinomas, or oral contraceptives and obesity associated with adenocarcinomas but less so with squamous cell carcinomas [47-52]. If indeed HPV infection is determinant for adenocarcinomas, we expected that the increasing incidence of adenocarcinomas would be preceded by an increasing prevalence of HPV in the general population. We found no nationwide monitoring of HPV prevalence. Nevertheless a most recent survey in 2003- 


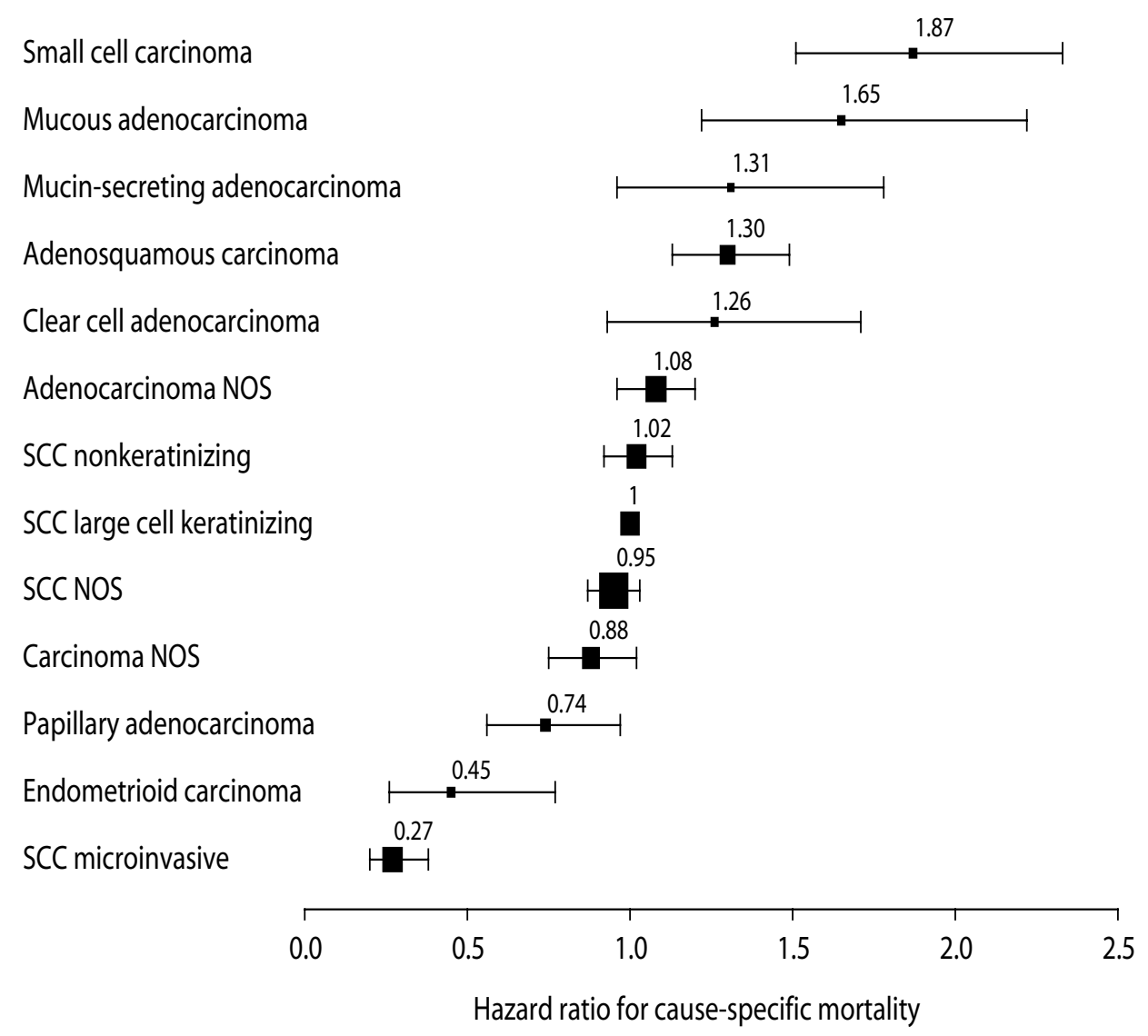

\section{Figure 3}

Ranking of histopathological types by cause-specific mortality hazard ratios. The hazard ratios were computed taking into account registry area, age, year of diagnosis, race, marital status, grade, stage, surgery, and radiotherapy. Horizontal bars: $95 \%$ confidence interval. Size of the boxes drawn as a function of the number of patients.

2004 reported that $26.8 \%$ of women overall tested positive for one or more strains of HPV [53]. That is a considerable increase as compared to a survey prevalence of $15.1 \%$ in 1997-1998 in Arizona among women aged 1835 years [54], or compared to estimates of $10 \%$ global prevalence in the early 1990's [55].

We also considered the trends of precursor lesions of adenocarcinomas. The SEER discontinued reporting of cervical in situ carcinomas in 1996, but cases registered between 1973 and 1995 were still available. There were 1,161 in situ adenocarcinoma, versus 116,666 other in situ (51,251 squamous, 47,650 in situ NOS, 17,492 cervical intraepithelial neoplasia grade 3 , and 273 miscellaneous). The mean age of the in situ adenocarcinoma patients was 38.2 years, and the mean age of the other in situ patients was 33.3 years. We plotted the respective incidences in Figure 4 . The plots were scaled using conventional standardization by subtracting the respective means and dividing by the respective standard deviations. Figure 4 show that in situ adenocarcinoma increased from 10 /year around 1975 to 129 /year around 1993. The increase was proportional to that of other in situ carcinomas. This similarity of the trends for the in situ carcinomas corroborates the concept of a common etiology. But the very small number of in situ adenocarcinomas as compared to other in situ carcinomas (Figure 4) or compared to invasive adenocarcinomas (Figure 1) suggests that the screening for early glandular lesions had a low sensitivity, and that adenocarcinomas might have been missed by conventional screening, possibly due to their location higher in the cervical canal $[31,36,56]$.

In view of the increasing trend of adenocarcinomas, their association with HPV, their poorer prognosis, and the young age at diagnosis discussed farther below, we argue for the need of improving screening for these tumors and for the opportunity of HPV vaccination [57-61]. 
Table 4: Multivariate analysis of cause-specific mortality based on 2,458 cases with complete pathological data

\begin{tabular}{|c|c|c|c|c|}
\hline & $\begin{array}{c}\text { A } \\
\text { Model including tumor } \\
\text { size and nodal variables }\end{array}$ & & $\begin{array}{c}\text { B } \\
\text { Model ignoring tumor } \\
\text { size and nodal variables }\end{array}$ & \\
\hline Variable & $\begin{array}{c}\text { Hazard ratio( } 6)(95 \% \text { confi- } \\
\text { dence interval })\end{array}$ & $\mathbf{P}$ & $\begin{array}{c}\text { Hazard ratio( }(6)(95 \% \text { confi- } \\
\text { dence interval) }\end{array}$ & $\mathbf{P}$ \\
\hline \multicolumn{5}{|l|}{ Pathology } \\
\hline Histology (1) & & $<0.001$ & & $<0.001$ \\
\hline SCC microinvasive & $1.26(0.40-4.04)$ & 0.693 & $0.61(0.19-1.93)$ & 0.407 \\
\hline Carcinoma NOS & $0.93(0.40-2.17)$ & 0.871 & $1.35(0.60-3.06)$ & 0.472 \\
\hline Adenocarcinoma excl. mucinous & $1.43(1.07-1.90)$ & 0.016 & $1.29(0.97-1.72)$ & 0.078 \\
\hline Adenosquamous carcinoma & $1.60(1.14-2.24)$ & 0.007 & $1.58(1.13-2.22)$ & 0.008 \\
\hline Mucinous & $1.94(1.07-3.49)$ & 0.028 & $2.08(1.16-3.75)$ & 0.015 \\
\hline Small cell & $7.03(3.95-12.5)$ & $<0.001$ & $7.59(4.28-13.4)$ & $<0.001$ \\
\hline Histological grade 3-4 (2) & $1.56(1.26-1.93)$ & $<0.001$ & $1.83(1.48-2.26)$ & $<0.001$ \\
\hline Log tumor size $(\mathrm{mm}){ }^{(3)}$ & $1.89(1.55-2.31)$ & $<0.001$ & & \\
\hline Log odds of nodal involvement (4) & $1.26(1.15-1.38)$ & $<0.001$ & & \\
\hline \multicolumn{5}{|l|}{ Stage } \\
\hline Historical stage localized (2) & & & $0.24(0.19-0.31)$ & $<0.001$ \\
\hline Stage II (5) & $0.99(0.62-1.58)$ & 0.966 & & \\
\hline Stage III (5) & $2.31(1.70-3.14)$ & $<0.001$ & & \\
\hline Stage IV (5) & $2.57(1.64-4.04)$ & $<0.001$ & & \\
\hline \multicolumn{5}{|l|}{ Other } \\
\hline Year of diagnosis & $0.97(0.94-0.99)$ & 0.016 & $0.96(0.94-0.99)$ & 0.011 \\
\hline African-American ethnicity (2) & $1.47(1.09-1.97)$ & 0.011 & $1.55(1.16-2.09)$ & 0.004 \\
\hline Hysterectomy (2) & $0.61(0.47-0.80)$ & $<0.001$ & $0.41(0.32-0.52)$ & $<0.001$ \\
\hline
\end{tabular}

(I) Reference level = non-microinvasive squamous cell carcinoma (SCC), all types.

(2) Binarized variable, coded I versus all other levels of the variable including missing.

(3) Untransformed tumor size displayed marked non-linearity.

(4) Log ((number of positive nodes +0.5$) /($ number of negative nodes +0.5$))[14]$.

(5) AJCC 3rd edition. Reference level $=$ stage I.

(6) Hazard ratio $>I$ indicates increased risk of dying from cervical cancer.

Some of the most extensive studies from the literature found that histopathological types were of limited prognostic value, or were significant only in some selected comparisons, or only within some subsets $[6,10,62]$. In a large study of 11,157 patients from the Patient Care and Evaluation Study comparing adenocarcinoma, squamous cell carcinoma, and adenosquamous carcinoma, Shingleton et al. found no significant differences in 5-year survival among the three tissue types [6]. In an earlier study of the SEER data, no evidence was found of survival differences between squamous cell carcinoma and adenocarcinoma [62]. In an investigation of 17 histological subtypes of non-squamous cell carcinoma of the uterine cervix identified from the Cancer Registry of Norway and histologically verified, Alfsen et al found that histological subtyping lacked significance except small cell carcinoma which was the only histologic subgroup of independent importance for prognosis [10].

These negative results could be interpreted as demonstrating that histopathology genuinely lack in sensitivity for predicting tumor behavior, or caused by wide variation in histopathologic definitions and criteria, lack of standardization in criteria and lack of reproducibility in their application [5]. The lack of reproducibility not only between different observers but also by the same observer was spotlighted in a review of tumor slides from nonsquamous cell carcinomas of the uterine cervix [63]. Slides previously reviewed [10] were blindly re-diagnosed more than one year later by the same pathologist (evaluation of intraobserver agreement) and independently by another pathologist (evaluation of interobserver agreement). The overall intraobserver and interobserver kappa index of agreement were respectively 0.53 and 0.44 , and the agreement was less than moderate (kappa $<0.40)$ in respectively 6 and 7 out of 17 histologic types [63]. The agreement was fair to poor for mixed carcinomas and adenocarcinomas NOS, poor for villoglandular and adenosquamous carcinomas, and the distinction of adenocarcinoma in situ from well-differentiated carcinoma proved difficult. Agreement for small cell and undifferentiated carcinomas was moderate (kappa > 0.50) 


\section{Non-invasive cervical carcinomas}

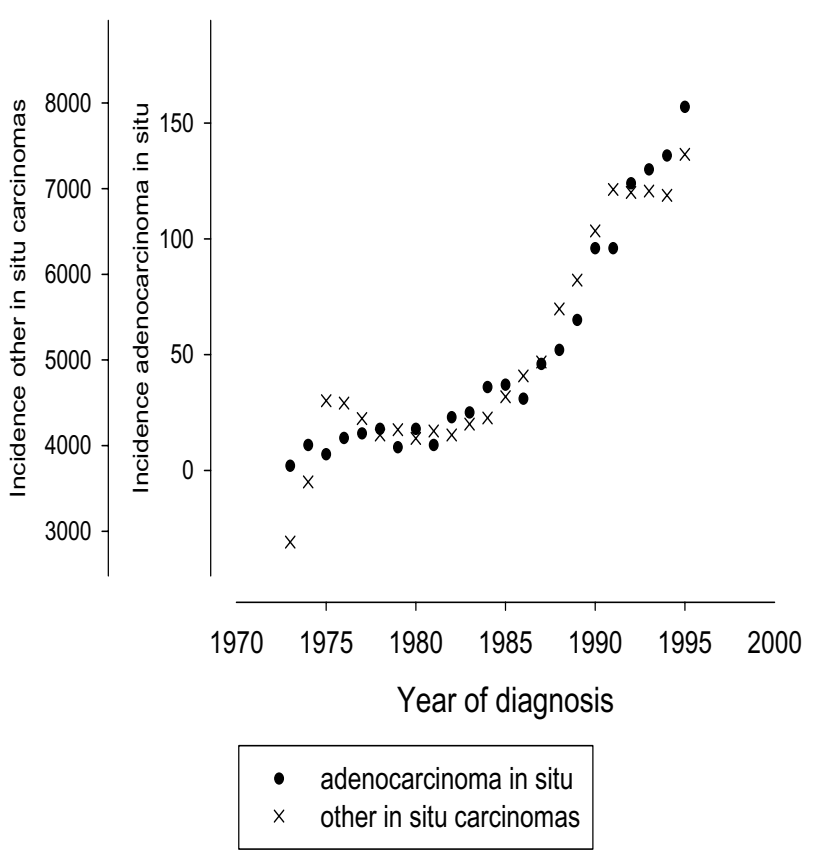

Figure 4

Numbers of newly diagnosed in situ carcinomas per year. The plots were centered around the respective means and were scaled by dividing with the respective standard deviations.

but the pathologists agreed upon the diagnosis only in 2/ 3 of these diagnoses.

On consideration that the SEER data come from widely differing practices and cover a large time period, there is a priori no reason to believe that the lack of agreement would be any better in the SEER data. Notwithstanding, our analyses find that histology is an important independent prognostic factor. Moreover, the synoptic view of Figure 3 corresponds surprisingly well with what might be expected of prognosis by the ordering of the hazard ratios: the lowest risk microinvasive SCC [64], the good prognosis of endometrioid carcinoma [65], the low risk but uncertain behavior of papillary adenocarcinoma [66], the closely clustered SCC types, the slightly poorer survival of clear cell adenocarcinoma [67], the adenosquamous usually recognized as an aggressive neoplasm $[4,68,69]$, the poor prognosis of mucinous adenocarcinomas [70], and the consistently poorest survival of small cell carcinoma [10]. The histopathological types appear to represent a continuum with largely overlapping confidence intervals which nevertheless do not preclude recognizing distinct clusters (Figure 3). Furthermore the different time trends summarized in Figure 1 suggest that the different histopathologies correspond to distinct biological entities.

Alfsen et al argued that the lack of significance for histopathologic subtyping of adenocarcinomas indicates the need for a simplified nomenclature for these tumors of the uterine cervix [10]. Most likely uncertainty or lack of reproducibility of histopathological subtyping also happened in the SEER data in view of the large confidence intervals (Table 3,4). This did not preclude the extraction of useful data. Our results argue that histopathologic types identify different tumors, provide valuable prognostic information, and are valuable for the early detection of unexpected trends.

We acknowledge several limitations to this study. Details such as whether the tumors were diagnosed by screening or by symptom occurrence, the type of screening, the HPV status, the status of surgical margins in operated cases, the radiation treatment procedures, the combination or not with chemotherapy, the presence or not of patient's comorbidities, were not available. The study could not assess to which extent histopathology should affect treatment decision. Factors other than histological type, such as tumor grade, stage or patient's ethnicity, were also important. These factors are not discussed, but clearly they show that the management of the patients cannot be based on histopathology alone. There were many missing data. Only $8 \%$ of the cases $(2,458$ out of 30,989$)$ had full pathological measurements. Even though the concordance of the analyses based on the reduced subsets suggest that the results are robust, the possibility of unknown confounding cannot be excluded. For all these reasons, caution is required, the results should only be considered as explorative.

\section{Conclusion}

In the present study, histological type was found to be an important independent prognostic factor in cervical cancer. The histological types associated with the poorest survival were small cell carcinoma, several subtypes of adenocarcinoma-mucinous, clear cell, and common type of adenocarcinoma- and adenosquamous carcinoma. Incidentally the data confirmed an increasing trend of adenocarcinomas despite an overall decline in the incidence of cervical cancers. The majority of the tumors were diagnosed in women younger than 50 years. The combination of young age, increasing trend, and poorer prognosis of adenocarcinomas questions the efficiency of conventional screening for these tumors, indicate the need to identify women who are at risk and who might most benefit from vaccination.

\section{Abbreviations}

AIC- Akaike Information Criterion. 
AJCC- American Joint Committee on Cancer.

HPV- human papillomavirus.

HR- hazard ratio.

ICDO- International Classification of Diseases for Oncology.

NOS- not otherwise specified.

SCC- squamous cell carcinoma.

SEER- Surveillance, Epidemiology, and End Results.

\section{Competing interests}

The author(s) declare that they have no competing interests.

\section{Authors' contributions}

ATV, VVH: original concept. ATV, CB, GC, MDR, GS, GV: critical appraisal and writing. VVH: responsible for the data integrity and compliance to the SEER Agreement; statistical analyses. All authors read and approved the final manuscript.

\section{Additional material}

\section{Additional File 1}

Check of proportional hazards for the manuscript's models of Tables 3, 4 . Figures are rho-values, correlation between residuals and survival time. Rho-values close to 0 indicate less departure from proportional hazards, whereas 1 is the theoretical maximum departure.

Click here for file

[http://www.biomedcentral.com/content/supplementary/14712407-7-164-S1.pdf]

\section{Additional File 2}

Functional forms of the effect of continuous variables on cause-specific mortality. The functional forms were computed from the manuscript's models of Table 3 (left graphs) and Table 4-A (right graphs). Dotted lines: $95 \%$ pointwise confidence interval.

Click here for file

[http://www.biomedcentral.com/content/supplementary/14712407-7-164-S2.pdf]

\section{Additional File 3}

Multivariate analysis of 30,989 cases of invasive cancer of the cervix: overall and cause-specific mortality. Results according to the overall and cause-specific mortality endpoints. The hazard ratios are globally comparable; only the cause-specific sub-table is reported in the manuscript. Click here for file

[http://www.biomedcentral.com/content/supplementary/14712407-7-164-S3.pdf]

\section{Acknowledgements}

Data abstraction was done according to the SEER Public-Use Data Agreement signed by VVH. The first version of the study was presented by ATV at the I I th Biennial International Gynecologic Cancer Society Meeting, Santa Monica, CA, USA, October 14-18, 2006. The authors gratefully acknowledge Christine Bouchardy for her help with revisions to the manuscript and updates to the literature.

\section{References}

I. Parkin DM, Bray FI, Devesa SS: Cancer burden in the year 2000. The global picture. Eur J Cancer 200I, 37 Suppl 8:S4-66.

2. Vizcaino AP, Moreno V, Bosch FX, Munoz N, Barros-Dios XM, Parkin $D M$ : International trends in the incidence of cervical cancer: I. Adenocarcinoma and adenosquamous cell carcinomas. Int J Cancer 1998, 75:536-545.

3. Vizcaino AP, Moreno V, Bosch FX, Munoz N, Barros-Dios XM, Borras J, Parkin DM: International trends in incidence of cervical cancer: II. Squamous-cell carcinoma. Int J Cancer 2000, 86:429-435.

4. Look KY, Brunetto VL, Clarke-Pearson DL, Averette HE, Major FJ, Alvarez RD, Homesley HD, Zaino RJ: An analysis of cell type in patients with surgically staged stage IB carcinoma of the cervix: a Gynecologic Oncology Group study. Gynecol Oncol 1996, 63:304-3II.

5. Singh N, Arif S: Histopathologic parameters of prognosis in cervical cancer--a review. Int J Gynecol Cancer 2004, I 4:74I-750.

6. Shingleton HM, Bell MC, Fremgen A, Chmiel JS, Russell AH, Jones WB, Winchester DP, Clive RE: Is there really a difference in survival of women with squamous cell carcinoma, adenocarcinoma, and adenosquamous cell carcinoma of the cervix? Cancer 1995, 76: 1948-1955.

7. Tiltman AJ: The pathology of cervical tumours. Best Pract Res Clin Obstet Gynaecol 2005, 19:485-500.

8. Eifel PJ, Burke TW, Morris M, Smith TL: Adenocarcinoma as an independent risk factor for disease recurrence in patients with stage IB cervical carcinoma. Gynecol Oncol 1995, 59:38-44.

9. Kleine W, Rau K, Schwoeorer D, Pfleiderer A: Prognosis of the adenocarcinoma of the cervix uteri: a comparative study. Gynecol Oncol 1989, 35: 145-149.

10. Alfsen GC, Kristensen GB, Skovlund E, Pettersen EO, Abeler VM: Histologic subtype has minor importance for overall survival in patients with adenocarcinoma of the uterine cervix: a population-based study of prognostic factors in $\mathbf{5 0 5}$ patients with nonsquamous cell carcinomas of the cervix. Cancer 200I, 92:247I-2483.

II. Institute NC: Surveillance, Epidemiology, and End Results (SEER) Program (www.seer.cancer.gov) Public-Use Data (1973-2002), National Cancer Institute, DCCPS, Surveillance Research Program, Cancer Statistics Branch, released April 2005, based on the November 2004 submission. 2005 [http://seer.cancer.gov]. Bethesda, MD, National Cancer Institute

12. Kaplan E, Meier P: Nonparametric estimation from incomplete observations. J Am Stat Assoc 1958, 53:457-48I.

13. Venables WN, Ripley BD: Modern Applied Statistics with S. Fourth Edition New York, Springer-Verlag; 2002: 172-176.

14. Vinh-Hung V, Verschraegen C, Promish DI, Cserni G, Van de Steene J, Tai P, Vlastos G, Voordeckers M, Storme G, Royce M: Ratios of involved nodes in early breast cancer. Breast Cancer Res 2004, 6:R680-R688.

15. Therneau TM, Grambsch PM: Modeling survival data: extending the Cox model New York, NY, Springer-Verlag; 2000:87-I52.

16. Howe HL, Wu X, Ries LA, Cokkinides V, Ahmed F, Jemal A, Miller B, Williams M, Ward E, Wingo PA, Ramirez A, Edwards BK: Annual report to the nation on the status of cancer, 1975-2003, featuring cancer among U.S. Hispanic/Latino populations. Cancer 2006, 107:1711-1742.

17. Kyndi M, Frederiksen K, Kruger KS: Cervical cancer incidence in Denmark over six decades (1943-2002). Acta Obstet Gynecol Scand 2006, 85: 106-III.

18. Levi F, Lucchini F, Negri E, Franceschi S, La VC: Cervical cancer mortality in young women in Europe: patterns and trends. Eur J Cancer 2000, 36:2266-227I.

19. Taylor R, Morrell S, Mamoon H, Wain G, Ross J: Decline in cervical cancer incidence and mortality in New South Wales in rela- 
tion to control activities (Australia). Cancer Causes Control 2006, 17:299-306

20. Borras JM, Sanchez V, Moreno V, Izquierdo A, Viladiu P: Cervical cancer: incidence and survival in migrants within Spain. J Epidemiol Community Health 1995, 49:153-157.

21. Hemminki K, Li X: Cancer risks in Nordic immigrants and their offspring in Sweden. Eur / Cancer 2002, 38:2428-2434.

22. Le GM, Gomez SL, Clarke CA, Glaser SL, West DW: Cancer incidence patterns among Vietnamese in the United States and Ha Noi, Vietnam. Int J Cancer 2002, 102:4I 2-4I7.

23. Jemal A, Siegel R, Ward E, Murray T, Xu J, Smigal C, Thun MJ: Cancer statistics, 2006. CA Cancer J Clin 2006, 56:106-130.

24. Armstrong LR, Hall HI, Wingo PA: Invasive Cervical Cancer Among Hispanic and Non-Hispanic Women --. United States, 1 992-- 1 999. MMWR, Weekly 2002, 5 I (47 I067-I070 [http:/ /www.cdc.gov/mmwr/preview/mmwrhtml/mm5/47a2.htm]

25. Hemminki K, Li X, Vaittinen P: Time trends in the incidence of cervical and other genital squamous cell carcinomas and adenocarcinomas in Sweden, 1958-1996. Eur J Obstet Gynecol Reprod Biol 2002, 1 01:64-69.

26. Liu S, Semenciw R, Mao Y: Cervical cancer: the increasing incidence of adenocarcinoma and adenosquamous carcinoma in younger women. CMAI 200I, I64:II5I-II52.

27. Sasieni $P$, Adams J: Changing rates of adenocarcinoma and adenosquamous carcinoma of the cervix in England. Lancet 200I, 357:1490-I493.

28. Lea JS, Sheets EE, Wenham RM, Duska LR, Coleman RL, Miller DS, Schorge JO: Stage IIB-IVB cervical adenocarcinoma: prognostic factors and survival. Gynecol Oncol 2002, 84: | I5-II9.

29. Visioli CB, Zappa M, Ciatto S, lossa A, Crocetti E: Increasing trends of cervical adenocarcinoma incidence in Central Italy despite Extensive Screening Programme, 1985-2000. Cancer Detect Prev 2004, 28:46I-464.

30. Schorge JO, Knowles LM, Lea JS: Adenocarcinoma of the cervix. Curr Treat Options Oncol 2004, 5: I 19-127.

31. Bray F, Carstensen B, Moller H, Zappa M, Zakelj MP, Lawrence G, Hakama M, Weiderpass E: Incidence trends of adenocarcinoma of the cervix in 13 European countries. Cancer Epidemiol Biomarkers Prev 2005, 14:2191-2199.

32. Walboomers JM, Jacobs MV, Manos MM, Bosch FX, Kummer JA, Shah KV, Snijders PJ, Peto J, Meijer CJ, Munoz N: Human papillomavirus is a necessary cause of invasive cervical cancer worldwide. J Pathol 1999, 189:12-19.

33. Bosch FX, Lorincz A, Munoz N, Meijer CJ, Shah KV: The causal relation between human papillomavirus and cervical cancer. J Clin Pathol 2002, 55:244-265.

34. Bohmer G, van den Brule AJ, Brummer O, Meijer CL, Petry KU: No confirmed case of human papillomavirus DNA-negative cervical intraepithelial neoplasia grade 3 or invasive primary cancer of the uterine cervix among $5 \mathrm{II}$ patients. Am J Obstet Gynecol 2003, 189: I 18-120.

35. Schiffman M, Kjaer SK: Chapter 2: Natural history of anogenital human papillomavirus infection and neoplasia. I Natl Cancer Inst Monogr 2003:14-19.

36. Bosch FX, De Sanjose S: Chapter I: Human papillomavirus and cervical cancer--burden and assessment of causality. I Natl Cancer Inst Monogr 2003:3-13.

37. zur Hausen H: Perspectives of contemporary papillomavirus research. Vaccine 2006, 24 Suppl 3:iii-iiv.

38. Woodman CB, Collins SI, Young LS: The natural history of cervical HPV infection: unresolved issues. Nat Rev Cancer 2007, 7:11-22.

39. Pirog EC, Kleter B, Olgac S, Bobkiewicz P, Lindeman J, Quint WG, Richart RM, Isacson C: Prevalence of human papillomavirus DNA in different histological subtypes of cervical adenocarcinoma. Am J Pathol 2000, I 57:1055- 1062.

40. Burk RD, Terai M, Gravitt PE, Brinton LA, Kurman RJ, Barnes WA Greenberg MD, Hadjimichael OC, Fu L, McGowan L, Mortel R, Schwartz PE, Hildesheim A: Distribution of human papillomavirus types 16 and 18 variants in squamous cell carcinomas and adenocarcinomas of the cervix. Cancer Res 2003, 63:7215-7220.

41. Altekruse SF, Lacey JV Jr., Brinton LA, Gravitt PE, Silverberg SG Barnes WA Jr., Greenberg MD, Hadjimichael OC, McGowan L, Mortel R, Schwartz PE, Hildesheim A: Comparison of human papillomavirus genotypes, sexual, and reproductive risk factors of cervical adenocarcinoma and squamous cell carcinoma:
Northeastern United States. Am J Obstet Gynecol 2003, 188:657-663.

42. An HJ, Kim KR, Kim IS, Kim DW, Park MH, Park IA, Suh KS, Seo EJ, Sung SH, Sohn JH, Yoon HK, Chang ED, Cho HI, Han JY, Hong SR, Ahn GH: Prevalence of human papillomavirus DNA in various histological subtypes of cervical adenocarcinoma: a population-based study. Mod Pathol 2005, I 8:528-534.

43. Chew GK, Cruickshank ME, Rooney PH, Miller ID, Parkin DE, Murray GI: Human papillomavirus 16 infection in adenocarcinoma of the cervix. Br J Cancer 2005, 93: I30I-I 304.

44. Bulk S, Berkhof J, Bulkmans NW, Zielinski GD, Rozendaal L, van Kemenade FJ, Snijders PJ, Meijer CJ: Preferential risk of HPVI6 for squamous cell carcinoma and of HPVI8 for adenocarcinoma of the cervix compared to women with normal cytology in The Netherlands. Br J Cancer 2006, 94: |7|-|75.

45. Castellsague X, Diaz M, De Sanjose S, Munoz N, Herrero R, Franceschi S, Peeling RW, Ashley R, Smith JS, Snijders PJ, Meijer CJ, Bosch FX: Worldwide human papillomavirus etiology of cervical adenocarcinoma and its cofactors: implications for screening and prevention. I Natl Cancer Inst 2006, 98:303-3I5.

46. Tawfik El-Mansi M, Cuschieri KS, Morris RG, Williams AR: Prevalence of human papillomavirus types 16 and 18 in cervical adenocarcinoma and its precursors in Scottish patients. Int J Gynecol Cancer 2006, 16:1025-103I.

47. Castellsague X, Bosch FX, Munoz N: Environmental co-factors in HPV carcinogenesis. Virus Res 2002, 89:19|-199.

48. Munoz N, Franceschi S, Bosetti C, Moreno V, Herrero R, Smith JS, Shah KV, Meijer CJ, Bosch FX: Role of parity and human papillomavirus in cervical cancer: the IARC multicentric case-control study. Lancet 2002, 359:1093-II01.

49. Green J, Berrington G, Sweetland S, Beral V, Chilvers C, Crossley B Deacon J, Hermon C, Jha P, Mant D, Peto J, Pike M, Vessey MP: Risk factors for adenocarcinoma and squamous cell carcinoma of the cervix in women aged 20-44 years: the UK National Case-Control Study of Cervical Cancer. Br J Cancer 2003, 89:2078-2086.

50. Haverkos HW, Soon G, Steckley SL, Pickworth W: Cigarette smoking and cervical cancer: Part I: a meta-analysis. Biomed Pharmacother 2003, 57:67-77.

5I. Lacey JV Jr., Swanson CA, Brinton LA, Altekruse SF, Barnes WA Gravitt PE, Greenberg MD, Hadjimichael OC, McGowan L, Mortel R, Schwartz PE, Kurman RJ, Hildesheim A: Obesity as a potential risk factor for adenocarcinomas and squamous cell carcinomas of the uterine cervix. Cancer 2003, 98:8|4-82।.

52. Appleby P, Beral V, Berrington de GA, Colin D, Franceschi S, Goodill A, Green J, Peto J, Plummer M, Sweetland S: Carcinoma of the cervix and tobacco smoking: collaborative reanalysis of individual data on $|3,54|$ women with carcinoma of the cervix and 23,017 women without carcinoma of the cervix from 23 epidemiological studies. Int J Cancer 2006, I I 8: | 48I - I 495.

53. Dunne EF, Unger ER, Sternberg M, McQuillan G, Swan DC, Patel SS, Markowitz LE: Prevalence of HPV infection among females in the United States. JAMA 2007, 297:8I3-819.

54. Giuliano AR, Papenfuss M, Abrahamsen M, Denman C, de Zapien JG Henze JL, Ortega L, Brown de Galaz EM, Stephan J, Feng J, Baldwin S, Garcia F, Hatch K. Human papillomavirus infection at the United States-Mexico border: implications for cervical cancer prevention and control. Cancer Epidemiol Biomarkers Prev 200I, I0:II29-II36.

55. Cates $W$ Jr.: Estimates of the incidence and prevalence of sexually transmitted diseases in the United States. American Social Health Association Panel. Sex Transm Dis 1999, 26:S2-S7.

56. Zielinski GD, Snijders PJ, Rozendaal L, Daalmeijer NF, Risse EK, Voorhorst F], Jiwa NM, van der Linden HC, de Schipper FA, Runsink AP, Meijer CJ: The presence of high-risk HPV combined with specific $\mathrm{p} 53$ and pI6INK4a expression patterns points to high-risk HPV as the main causative agent for adenocarcinoma in situ and adenocarcinoma of the cervix. J Pathol 2003 , 201:535-543.

57. Harper DM, Franco EL, Wheeler CM, Moscicki AB, Romanowski $B$ Roteli-Martins CM, Jenkins D, Schuind A, Costa Clemens SA, Dubin G: Sustained efficacy up to 4.5 years of a bivalent LI virus-like particle vaccine against human papillomavirus types 16 and 18: follow-up from a randomised control trial. Lancet 2006, 367:1247-1255. 
58. Roden R, Wu TC: How will HPV vaccines affect cervical cancer? Nat Rev Cancer 2006, 6:753-763.

59. Garland SM, Hernandez-Avila M, Wheeler CM, Perez G, Harper DM, Leodolter S, Tang GW, Ferris DG, Steben M, Bryan J, Taddeo FJ, Railkar R, Esser MT, Sings HL, Nelson M, Boslego J, Sattler C, Barr E, Koutsky LA: Quadrivalent vaccine against human papillomavirus to prevent anogenital diseases. N Engl J Med 2007, 356:1928-1943.

60. Group FIIS: Quadrivalent vaccine against human papillomavirus to prevent high-grade cervical lesions. N Engl J Med 2007, 356:1915-1927.

6I. Saslow D, Castle PE, Cox IT, Davey DD, Einstein MH, Ferris DG, Goldie SJ, Harper DM, Kinney W, Moscicki AB, Noller KL, Wheeler CM, Ades T, Andrews KS, Doroshenk MK, Kahn KG, Schmidt C, Shafey O, Smith RA, Partridge EE, Garcia F: American Cancer Society Guideline for human papillomavirus (HPV) vaccine use to prevent cervical cancer and its precursors. CA Cancer J Clin 2007, 57:7-28.

62. Kosary CL: FIGO stage, histology, histologic grade, age and race as prognostic factors in determining survival for cancers of the female gynecological system: an analysis of 1973-87 SEER cases of cancers of the endometrium, cervix, ovary, vulva, and vagina. Semin Surg Oncol 1994, 10:31-46.

63. Alfsen GC, Reed W, Abeler VM: Reproducibility of classification in non-squamous cell carcinomas of the uterine cervix. Gynecol Oncol 2003, 90:282-289.

64. Lecuru F, Neji K, Robin F, Vilde F, Taurelle R: [Microinvasive carcinoma uterine cervix. Which approach in 1998?]. Bull Cancer 1998, 85:319-327.

65. Saigo PE, Cain JM, Kim WS, Gaynor JJ, Johnson K, Lewis JL Jr.: Prognostic factors in adenocarcinoma of the uterine cervix. Cancer 1986, 57: I584-1593.

66. Zhou C, Gilks CB, Hayes M, Clement PB: Papillary serous carcinoma of the uterine cervix: a clinicopathologic study of 17 cases. Am J Surg Pathol 1998, 22: I I3-120.

67. Herbst AL, Norusis MJ, Rosenow PJ, Welch WR, Scully RE: An analysis of 346 cases of clear cell adenocarcinoma of the vagina and cervix with emphasis on recurrence and survival. Gynecol Oncol 1979, 7:1 II-122.

68. Gallup DG, Harper RH, Stock RJ: Poor prognosis in patients with adenosquamous cell carcinoma of the cervix. Obstet Gynecol 1985, 65:416-422.

69. Lea JS, Coleman RL, Garner EO, Duska LR, Miller DS, Schorge JO: Adenosquamous histology predicts poor outcome in lowrisk stage IBI cervical adenocarcinoma. Gynecol Oncol 2003 91:558-562

70. Ueki M, Ueda M, Okamura S, Yamada T: Clinicopathological features of well-differentiated cervical adenocarcinoma with abundant mucus secretion. J Med 1995, 26:17-30.

\section{Pre-publication history}

The pre-publication history for this paper can be accessed here:

http://www.biomedcentral.com/1471-2407/7/164/pre pub
Publish with Biomed Central and every scientist can read your work free of charge

"BioMed Central will be the most significant development for disseminating the results of biomedical research in our lifetime. "

Sir Paul Nurse, Cancer Research UK

Your research papers will be:

- available free of charge to the entire biomedical community

- peer reviewed and published immediately upon acceptance

- cited in PubMed and archived on PubMed Central

- yours - you keep the copyright
BioMedcentral 